\title{
Detection of Ostreid Herpesvirus 1 from adult Pacific Oysters Crassostrea gigas Cultured in Korea
}

\author{
Bo Young Jee ${ }^{1}$, Su Jin Lee ${ }^{2}$, Mi Young Cho ${ }^{1}$, Soon Jeong Lee ${ }^{1}$, Jin Woo Kim ${ }^{1}$,Seung Hyuk Choi ${ }^{2}$, \\ Hyun Do Jeong ${ }^{2}$ and Ki Hong Kim \\ ${ }^{1}$ Aquatic Life Disease Control Division, National Fisheries Research and Development Institute, Busan 619-902, Korea \\ ${ }^{2}$ Department of Aquatic Life Medicine, Pukyong National University, Busan 608-737, Korea
}

\begin{abstract}
The presence of ostreid herpesvirus 1 (OsHV-1) and the percentage of viral DNA detected in Pacific oyster Crassostrea gigas adults were investigated monthly between May and November 2012 at three locations along the southern coast of Korea. Among 210 oysters examined by polymerase chain reaction (PCR) analysis, OsHV-1 DNA was detected in only one oyster collected in August. The low detection rate of OsHV-1 DNA was consistent with the lack of reported OsHV-1-associated disease in C. gigas cultured in Korea. The sequence of the present PCR product amplified with the $\mathrm{C} 2 / \mathrm{C} 6$ primer pair was identical to that of OsHV-1 $\mu$ Var except for one nucleotide, and the sequence amplified with Del36-37F2/Del36-37R showed a 605-bp deletion as in OsHV-1 $\mu$ Var. Although these sequence data are insufficient to determine genotype, the results suggest that the herpesvirus detected was similar to OsHV-1 $\mu$ Var. This is the first report on the presence of OsHV-1 in adult Pacific oysters cultured in Korea.
\end{abstract}

Key words: Ostreid herpesvirus 1, Crassostrea gigas adults, PCR analysis

\section{Introduction}

Since Farley et al. (1972) first described a herpes-type virus in the Eastern oyster Crassostrea virginica, herpes or herpeslike viruses have been reported worldwide from various bivalves including oysters, clams, and scallops (Renault and Novoa, 2004). Minson et al. (2000) named a virus isolated from infected Pacific oyster Crassostrea gigas larvae as ostreid herpesvirus 1 (OsHV-1), and Davison et al. (2005) reported the full genome sequence of OsHV-1 (GenBank accession no. AY509253). Initially, two OsHV-1 genotypes, OsHV-1 reference and OsHV-1 var, were reported in France (Arzul et al., 2001), but additional genotypes such as OsHV-1 microvariant ( $\mu$ Var) (Segarra et al., 2010) and OsHV-1 $\mu$ Var $\Delta 9$ (Martenot et al., 2011) have been newly added. OsHV-1 has been detected in C. gigas spat mortalities in France since 1993. However, severe mortality outbreaks in Pacific oyster spat and juveniles have been reported in different member states of the European Union including France and Ireland since 2008, and OsHV-1 $\mu$ Var has been proposed as the possible culprit (Segarra et al., 2010; Schikorski et al., 2011a, 2011b).

Korea is among the top three countries in the world for production of Pacific oysters. However, as oyster farms are concentrated on the southern coastal area of Korea, an outbreak of highly infectious disease at a farm can bring highly disastrous results in the Korean oyster aquaculture industry. Although Moss et al. (2007) reported the presence of molluscan herpesvirus from Crassostrea ariakensis collected from Korea, no reports have been published on the presence of OsHV-1 in Korean Pacific oyster. The purpose of this study was to inves-
Open Access http://dx.doi.org/10.5657/FAS.2013.0131

This is an Open Access article distributed under the terms of the Creative Commons Attribution Non-Commercial License (http://creativecommons. org/licenses/by-nc/3.0/) which permits unrestricted non-commercial use, distribution, and reproduction in any medium, provided the original work is properly cited. pISSN: 2234-1749 eISSN: 2234-1757
Received 10 April 2013; Revised 21 May 2013

Accepted 12 June 2013

*Corresponding Author

E-mail:khkim@pknu.ac.kr 
tigate the presence and prevalence of OsHV-1 in adult Pacific oysters in Korea.

\section{Materials and Methods}

\section{Oysters}

Crassostrea gigas adults (1-2 years old) were collected monthly between May 2012 and November 2012 from oyster farms located at Tongyeong, Goseong, and Geoje on the southern coast of Korea. Immediately after the oysters arrived in the laboratory each month, 30 oysters (10 oysters from each region) were sampled, and gill and mantle tissues were excised to analyze for the presence of OsHV-1 by polymerase chain reaction (PCR).

\section{PCR analysis}

The excised gill and mantle were lysed by adding $500 \mu \mathrm{L}$ of lysis buffer containing Proteinase $\mathrm{K}$ and incubated in a shaking water bath at $60^{\circ} \mathrm{C}$ for $3 \mathrm{~h}$ to extract total DNA. Then, 250 $\mu \mathrm{L}$ of $6 \mathrm{M} \mathrm{NaCl}$ was added to each tube, followed by vigorous shaking of the tubes 20 times and a 10-min incubation on ice. The supernatants were recovered by centrifugation at $10,000 \mathrm{~g}$ for $10 \mathrm{~min}$, mixed with $650 \mu \mathrm{l}$ isopropanol, and centrifuged at $10,000 \mathrm{~g}$ for $10 \mathrm{~min}$. The resulted pellet was further air-dried for $5 \mathrm{~min}$ and eluted with RNAse-free water.

The primers used are listed in Table 1 . Primary PCR reactions were conducted with primer pairs of C13/C5 (open reading frame [ORF]4), C13/C6 (ORF4), and Del-F/Del-R (ORF35, 36, 37, and 38), and amplification conditions were one cycle of $3 \mathrm{~min}$ at $95^{\circ} \mathrm{C}$ (initial denaturation), 30 cycles of $30 \mathrm{~s}$ at $95^{\circ} \mathrm{C}, 30 \mathrm{~s}$ at $55^{\circ} \mathrm{C}$, and $30 \mathrm{~s}$ at $72^{\circ} \mathrm{C}$, followed by 7 min at $72^{\circ} \mathrm{C}$. Primer pairs used for nested PCR were $\mathrm{C} 2 / \mathrm{C} 4$, C2/C6, and Del36-37F/Del36-37R, respectively, and $0.2 \mu \mathrm{l}$ of each primary PCR product was used as the template. The PCR conditions for the nested PCR were the same as those for the

Table 1. Oligonucleotides used in this study

\begin{tabular}{ll}
\hline Primers & \multicolumn{1}{c}{ Sequence $\left(\mathbf{5}^{\prime} \rightarrow \mathbf{3}^{\prime}\right)$} \\
\hline $18 \mathrm{~S}-\mathrm{F}$ & GTAACGGGTAACGGGGATC \\
$18 \mathrm{~S}-\mathrm{R}$ & CCCCGTCAGTCCCTCTTAAT \\
C13 & CCTCGAGGTAGCTTTTGTCAAG \\
C5 & CCGTGACTTCTATGGGTATGTCAG \\
C6 & GTGCACGGCTTACCATTTTT \\
Del-F & GCTGCATATTGTCCTTCTAGC \\
Del-R & GATGAAAGTGCAGAAGAATACACTG \\
C2 & CTCTTTACCATGAAGATACCCACC \\
C4 & GCAGTTGTGGTATACTCGAGATTG \\
Del36-37F & ATACGATGCGTCGGTAGAGC \\
Del36-37R & CGAGAACCCCATTCCTGTAA \\
\hline
\end{tabular}

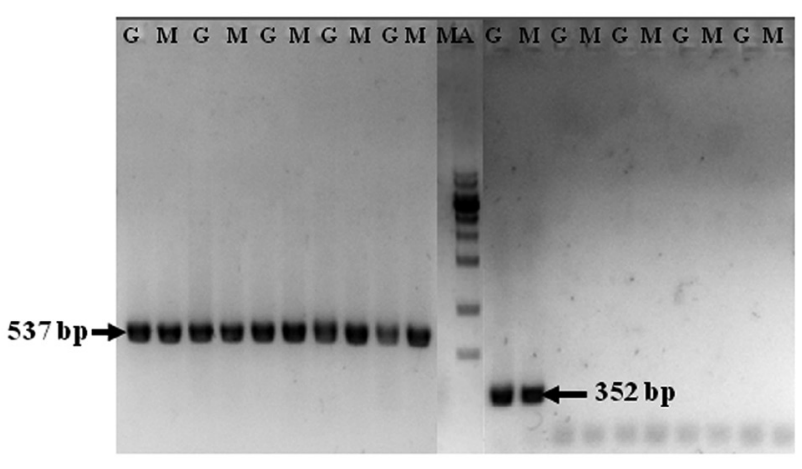

Fig. 1. $P C R$ analysis of ostreid herpesvirus $1(\mathrm{OsHV}-1)$ in the gill (G) and the mantle (M) of Crassostrea gigas collected from Tongyeong in August. Primary PCR was conducted with $\mathrm{C} 13 / \mathrm{C} 5$ primer pair, and nested PCR was done with $\mathrm{C} 2 / \mathrm{C} 4$ primer pair (right $353 \mathrm{bp}$ ). As a control, $18 \mathrm{~S}$ ribosomal RNA gene was amplified with 18S-F/18S-R primer pair (left $537 \mathrm{bp}$ ). The figure is a part of the PCR results to show the positive band amplified with C2/C4 primer pair. MA, 1 kb ladder (Bioneer, Korea).

primary PCR. PCR products were analyzed on a $1 \%$ agarose gel containing Midori Green Advanced DNA stain (Nippon Genetics, Düren, Germany) for visualization, purified using a gel purification kit (Nucleogen, Seoul, Korea), subcloned into pGEM-T Easy Vector (Promega, Madison, WI, USA), and sequenced. Multiple sequence alignments were generated using the CLUSTALW 1.8 program.

\section{Results}

In total, 210 Pacific oysters were PCR-analyzed to detect OsHV-1 DNA. The band corresponding to the partial $18 \mathrm{~S}$ ribosomal RNA gene was detected from all analyzed specimens (Fig. 1). No amplified band was identified in any of the samples by primary PCR with the primer pairs for amplifying OsHV-1 DNA. However, nested PCR with the C2/C4 primers amplified a band of the expected size (352 bp) from only one oyster (Fig. 1), which was collected from Tongyeong in August; thus, the percentage of OsHV-1 DNA detection in $C$. gigas adults was less than $1 \%(1 / 210)$.

The sequence of the $\mathrm{C} 2 / \mathrm{C} 6 \mathrm{PCR}$ product of the positive sample showed deletion of 13 consecutive nucleotides, and another 11 nucleotides were sporadically changed or deleted when compared to the OsHV-1 reference sequence (Fig. 2). Only one G (Fig. 2) was deleted in the present sample compared to that in the OsHV-1 $\mu$ Var sequence.

Nested PCR with the Del36-37F/Del36-37R primers amplified a band of expected size ( $384 \mathrm{bp}$ ) that represented a deletion of the middle region of the gene corresponding to 605 nucleotides in the OsHV-1 reference sequence (Fig. 3A). A comparison of the present sequence with those recorded in other countries was identical except for two nucleotides (Fig. 3B). 


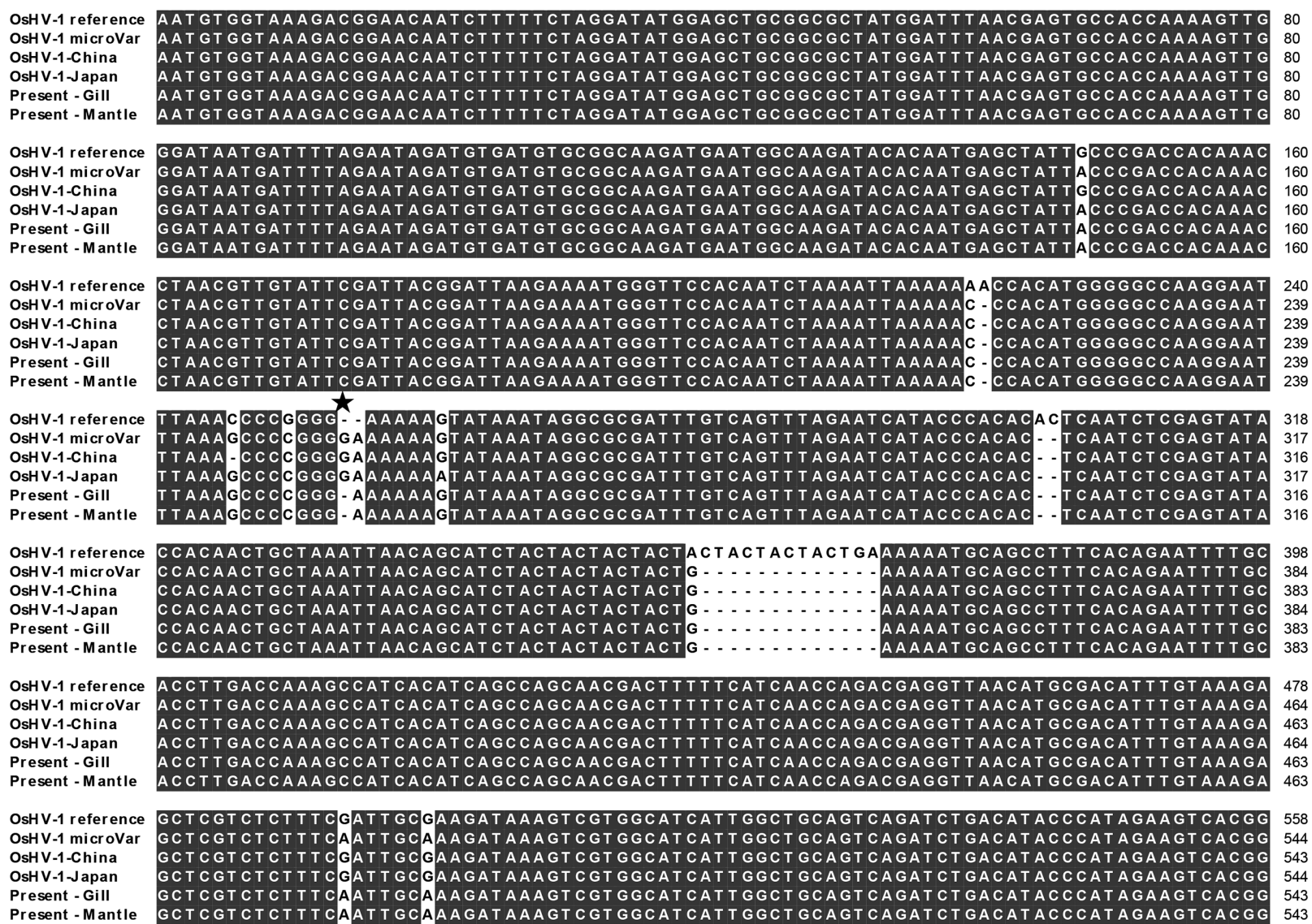

Fig. 2. Multiple alignment of nucleotides sequence of the present C2/C6 PCR product with that of ostreid herpesvirus 1 (OsHV-1) reference (AY509253), OsHV-1 $\mu$ Var (HQ842610.1), and OsHV-1 recorded from China (JN800132.1), and Japan (JN800133.1). Identical nucleotides are indicated by black shading. $\star$, indicates a different nucleotide of the present sample from OsHV-1 $\mu$ Var.

\section{Discussion}

We report for the first time the presence of OsHV-1 from Pacific oyster adults in Korea. Although OsHV-1 has been associated with mass mortalities of Pacific oyster larvae or spat, adult oysters asymptomatically carrying the virus could have the potential to transmit OsHV-1 to $C$. gigas larvae or other bivalve species.

According to the results of Moss et al. (2007), C. ariakensis collected from three regions in Korea showed a prevalence of molluscan herpesvirus of up to $40 \%$, whereas $C$. gigas was completely negative for the herpesvirus (all sampled oysters from Korea were considered adults based on the description). Similarly, the percentage of OsHV-1 DNA that we detected in Pacific oyster adults was very low $(<1 \%)$. This result was extremely low compared to the OsHV-1 occurrence in adult $\mathrm{Pa}$ cific oyster in France, where prevalence is above 70\% (Arzul et al., 2002; Martenot et al., 2011). The low detection rate of OsHV-1 DNA observed in the present study is consistent with the lack of reported OsHV-1-associated disease in C. gigas cultured in Korea.

One of the main differences in the nucleotide sequence of OsHV-1 $\mu$ Var from that of OsHV-1 reference is a partial deletion of the microsatellite zone of the region amplified with the primer pair C2 and C6 (Segarra et al., 2010). The deleted nucleic acids included three consecutively repeated "CTA," followed by a "CTGA." The C2/C6 sequence of the present OsHV-1 showed the same deletion and was identical with that of OsHV-1 $\mu$ Var except for one nucleotide, whereas the previously reported OsHV-1 from China and Japan showed four and three different nucleotides, respectively, compared to that of OsHV-1 $\mu$ Var. Renault et al. (2012) reported that all specimens identified as OsHV-1 $\mu$ Var show a large deletion (605 bp) of the amplicon with the primer pair Del36-37F2 and Del 36-37R, and the present virus specimen also had the same deletion. Considering the full genome size of OsHV-1, the present sequence data are insufficient to determine the genotype; however, our results suggest that the herpesvirus detected in this study was similar to OsHV-1 $\mu$ Var. 


\section{A}

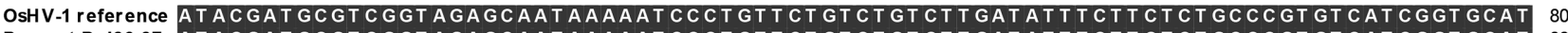
Present Del36-37 AT ACGAT GCGT CGGT AGAGCAATAAAAAT C C CT GT T CT GT CT GT CT T GATATT T CT T CT CT GCCCGT GTCAT CGGT GCAT 80 OsHV-1 reference ATCT T GAT CGGCAAGGAT TCCT TACT TCCT T GGGACCT CT GAT TGGTAGT GAAT CAAAAT T GCAAT TGT T TCT GAT T GTA 160 Present Del36-37 ATCTTGATCGGCAAGGATTCCTTACTTCCTTGGGACCTCTGATTGGTAGTGAATCAAAAT GCAATTGTTCTGATTGTA 160 OsHV-1 reference AT T T CT T CT GT AAGGT T TAGCT T CAGT T TAAGAT T GT T T CTCT T TCCACGTCT GT T T CTAAT GGGAGCCATGGT GATGAA 240 Present Del36-37 AT T C T T CT GTAAGGT TAGCT T CAGT T TAAGAT T GT T T CT CT T TCACGTCTGTTTCTAAT GGGAGCCATGGT GATGAA 240 OsHV-1 reference TGAAGT T GAAAGACGAAAATCAACAAAATATATAGT CT TTTGTAATATGTCGCAGAAAAACTAATAGTGAAAGTAACTTC 320 Present Del36-37 T GAAGT T GAAAGACGAAAAT CAACAAAAT AT AT A . . . . . . . . . . . . . . . . . . . . . . . . . . . . . .

OsHV-1 reference TTGGAAT CGGTCCTCGGAGGATATAAAGT T T GACAAAGAGT GCAAT GAGGGCTGCCCAAAT CACTATCATAT TGATGAT T 400

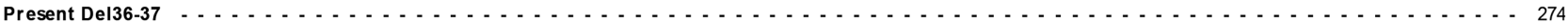
OsHV-1 reference CT GAAAAGCAAT AGAACT CT CT GCCAT GCCTGTCTCTTTGGTTTCT TCACGATTATGTATTGTGGTTTAGCAGGGATAAG 480

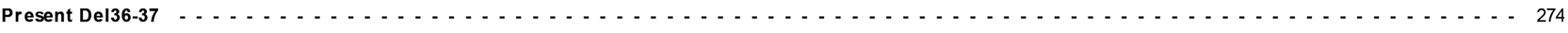
OsHV-1 reference TTCAGATTCTTGCTCAATCTCGCACACTGTTTGCTCTGTAGTAGACATATTGAAAAATGAAAGTGGTTTTCGTAAACTCA 560

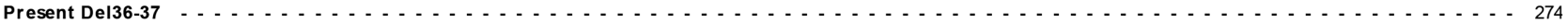

OsHV-1 reference AACT T T T TT TATAGTT T TT TAAAAAAACATGGTCCTAGTCAAAATCTCTATAAAAGATGCTAAAATATCCACCAGCCCG 640

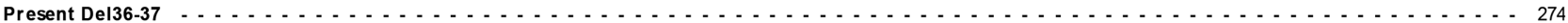
OsHV-1 reference CGT TAAGACATTGGTCTCCACAATACACATGATCCTAGATAATTCCCTGCCAACACTCTTGATCACAGCTCTTTCTTCCA 720

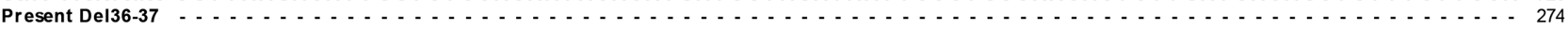
OsHV-1 reference TCGTGATATTATCGGGAGGGAATTGTCGGTTGAGTATCTGTCTATCATTGTGATCGTAAAGGAAATGTGCATTTATCGCG 800

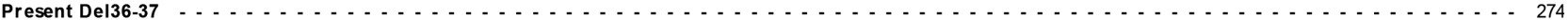
OsHV-1 reference CGATGGT T CCT CGTGAAAAAAAT CATCAAAT TGT TCTAATACTT CGGGGCTGAACGGTGGTACAT TGGTTACAT CT T T T A 880 Present Del36-37 ... . . . . . . . . . . . . . . . . . . . . . . . . . . . . . . . . . . . . . . . . . OsHV-1 reference CT AT CT T T T T GGCAT TGAT GAT TAT GCT T T T GAGT ATCGT CCACAAGTACCT T GT AT GT GGTATAT CT T C CCATAAT GGA 960 Present Del36-37 CTAT CT T T T GGGAT TAAT GAT TACGCTTTTGAGTATCGT CCACAAGTACCTTGTAT GTGGTATATCTTCCCATAATGGA 354 OsHV-1 reference TATTCCATGTTTACAGGAAT GGGGTT CTCG 990 Present Del36-37 TAT T C CAT GT T TACAGGAAT GGGGT T CT CG 384

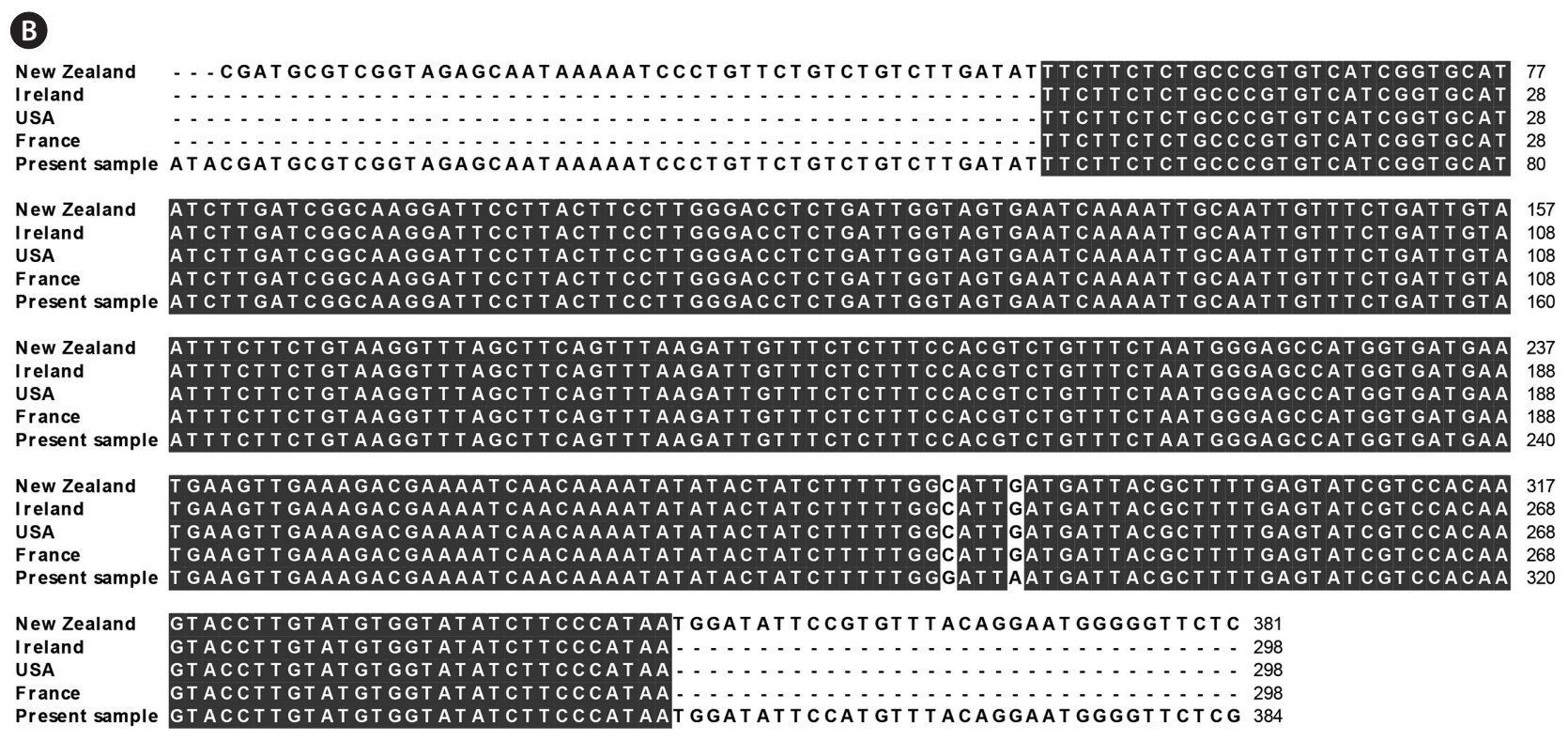

Fig. 3. Multiple alignment of nucleotides sequence of the PCR product (Del36-37F and Del36-37R primers) with ostreid herpesvirus 1 (OsHV-1) reference (A), and with OsHV-1 recorded from New Zealand (JN800252.1), Ireland (JN800250.1), USA (JN800249.1) and France (JN800248.1) (B). Identical nucleotides are indicated by black shading.vv 


\section{Acknowledgements}

This research was supported by the National Fisheries Research \& Development Institute (NFRDI) (RP-2013-AQ-107)

\section{References}

Arzul I, Renault T, Lipart C and Davison AJ. 2001. Evidence for interspecies transmission of oyster herpesvirus in marine bivalves. J Gen Virol 82, 865-870.

Arzul I, Renault T, Thébault A and Gérard A. 2002. Detection of oyster herpesvirus DNA and proteins in asymptomatic Crassostrea gigas adults. Virus Res 84, 151-160.

Davison AJ, Trus BL, Cheng N, Steven AC, Watson MS, Cunningham C, Le Deuff RM and Renault T. 2005. A novel class of herpesvirus with bivalve hosts. J Gen Virol 86, 41-53.

Farley CA, Banfield WG, Kasnic G Jr and Foster WS. 1972. Oyster herpes-type virus. Science 178, 759-760.

Martenot C, Oden E, Travaillé E, Malas JP and Houssin M. 2011. Detection of different variants of Ostreid Herpes virus1 in the Pacific oyster, Crassostrea gigas between 2008 and 2010. Virus Res 160, 25-31.

Minson AC, Davison A, Eberle R, Desrosiers RC, Fleckenstein B, McGeoch DJ, Pellett PE, Roizman B and Studdert MJ. 2000. Family Herpesviridae. In: Virus Taxonomy. Seventh Report of the Inter- national Committee on Taxonomy of Viruses. van Regenmortel MHV, Fauquet CM, Bishop DHL, Carstens EB, Estes MK, Lemon SM, Maniloff J, Mayo MA, McGeoch DJ, Pringle CR and Wickner RB, eds. Academic Press, San Diego, CA, US, pp. 203-225.

Moss JA, Burreson EM, Cordes JF, Dungan CF, Brown GD, Wang A, Wu X and Reece KS. 2007. Pathogens in Crassostrea ariakensis and other Asian oyster species: implications for non-native oyster introduction to Chesapeake Bay. Dis Aquat Org 77, 207-223.

Renault T and Novoa B. 2004. Viruses infecting bivalve molluscs. Aquat Living Resour 17, 397-409.

Renault T, Moreau P, Faury N, Pepin JF, Segarra A and Webb S. 2012. Analysis of clinical ostreid herpesvirus 1 (Malacoherpesviridae) specimens by sequencing amplified fragments from three virus genome areas. J Virol 86, 5942-5947.

Schikorski D, Faury N, Pépin JF, Saulnier D, Tourbiez D and Renault T. 2011a. Experimental ostreid herpesvirus 1 infection of the Pacific oyster Crassostrea gigas: kinetics of virus DNA detection by q-PCR in seawater and in oyster samples. Virus Res 155, 28-34.

Schikorski D, Renault T, Saulnier D, Faury N, Moreau P and Pépin JF. 2011b. Experimental infection of Pacific oyster Crassostrea gigas spat by ostreid herpesvirus 1: demonstration of oyster spat susceptibility. Vet Res 42, 27.

Segarra A, Pépin JF, Arzul I, Morga B, Faury N and Renault T. 2010. Detection and description of a particular Ostreid herpesvirus 1 genotype associated with massive mortality outbreaks of Pacific oysters, Crassotrea gigas, in France in 2008. Virus Res 153, 92-99. 